\title{
Modern Business Teaching: The Sable Labor Market Provision for the Emerging Generations
}

\author{
KRISTAPS LESINSKIS*1, INESE MAVLUTOVA ${ }^{2}$, LIGA PEISENIECE ${ }^{3}$, JANIS HERMANIS ${ }^{4}$, \\ ELINA PEISENIECE ${ }^{5}$, OLGA POKATAYEVA ${ }^{6}$ \\ 1,2,3,4,5 Department of Management, SCHOOL OF BUSINESS AND FINANCE, LATVIA. \\ *E-mail: kristaps.lesinskis@ba.Iv \\ ${ }^{6}$ Department of Economics, CLASSICAL PRIVATE UNIVERSITY, LATVIA.
}

\begin{abstract}
Models used in education that were exploited in the 20th century are now under revision, as educators attempt to identify what is suitable to be kept and what needs to be changed and redefined for the 21st century. There are wide discussions on how to appropriately adjust entrepreneurship education methods to the changing expectations of emerging generations. The goal of the study is to identify more appropriate teaching methods for entrepreneurship education in the case of Latvia, country that has had one of the highest entrepreneurial activity in the European Union for many years. Conclusion from the primary research done by authors is that sample of respondents representing Generation $Z$ highly value the application and effectiveness of modern teaching methods in entrepreneurship studies, however, the evaluation of different methods differs significantly depending on the type of learning preferred.
\end{abstract}

Keywords: Generation Z; entrepreneurship education, classical teaching methods, IT tool, modern teaching methods

JEL Classification: A29, D83 E20 


\section{Introduction.}

The aim of the research is to identify underlying forces leading to the changes taking place in the financial sector due to the digitalization.

In the midst of the technological progress all over the world, there is an ongoing discussion on how to appropriately adjust entrepreneurship education methods to the changing expectations as new generations evolve or emerge close to the time when serious career decisions are made. Models used in education that were exploited in the 20th century are now under revision, as professionals in the field attempt to identify what is suitable to be kept and what needs to be changed and redefined for the 21st century.

The authors of the paper choosed to study modern teaching methods in entrepreneurship and their suitability for Generation Z. It is believed that Generation Z significantly differs from the previous ones and the main differences are related to technology adoption and innovation.

Latvia is one of the understudied countries in this European region when it comes to entrepreneurship. The case is worth attention and research. There are several reasons for that. From year to year, according to Global Entrepreneurship Monitor adult population studies, Latvia ranks first or one of the first in terms of entrepreneurial activity and scores very high when measurements assessing early-stage entrepreneurship are made.

\section{Theoretical framework.}

Starting this study, authors followed the objectives of the Europe 2020 Strategy and the Entrepreneurship 2020 Action Plan which agrees that policies promoting entrepreneurship have to be coordinated with education policies, at both national and European levels. Mavlutova et al [1] assert that the analysis of globally comparable statistical data shows that there are low entrepreneurial spirits, high doubts and fears to start entrepreneurial activities among the European citizens.

Digitalization creates more and more possibilities in future to use modern teaching and learning methods, automatic digital tools in education and solutions in form of artificial intelligence. Audretsch [2], Uvarova, Mavlutova, Atstaja [3] and Petrova et al [4] describe the important role of innovative teaching methods in developing an entrepreneurial mindset, behaviour and mentalityin society.

Neck and Greene [5] outline the methods that should be applied in order to stimulate entrepreneurship during the studies. They suggested several methods that foster achievement of better results and contribute to successful business education: a set of practice-based pedagogical approaches, including starting entrepreneurship as part of the study plan, different business games and business simulations, reflection and design thinking.

Fiet [6] suggests that entrepreneurial education is associated with career choice and personal skills. For example, research finds that entrepreneurial education is positively related to entrepreneurial attitudes and skills. Hattab [7] argued that entrepreneurship education can develop entrepreneurial intentions through individual attitudes and cognition.

Some authors believe that Generation Z are those born between 1997 and the second decade of the 21st century. Other scholars believe that Generation $Z$ is people born after 1995 [8]. Some other scientists believe that Generation Z was born between 1996 and 2010. The point on which there is a consensus among experts: the generation $Z$ does not know the world without the internet and virtual reality has become as real as the physical world in their lives.

Another characteristic of the Generation $Z$ is the global perspective of their views and thinking, tolerance to diversity thanks to the development of the Internet, social platforms and digital opinion leaders. In many ways, the Generation $\mathrm{Z}$ is good news for managers- they are cautious, hard-working, want to build a career in a stable environment [9]. The goals of the company are important to this generation, but they are not vital. The Generation $Z$ wants to adapt the company's goal to their 
personal needs [10].

The authors agree with Scholz and Rennig [11] that significant differences exist in the profile of generation $\mathrm{Z}$ representatives in different parts of the world, among different European countries, or even within a single country, but definetely the important characteristic of Generation $Z$ is the usage of IT tools.

Generation Z has a number of characteristics that are not typical of the previous Generation X: ability to operate in both real and virtual worlds; good ability to quickly obtain and disseminate information (although the quality of information can be more problematic), communicate via social media [12], as well as in multitasking, less able to distinguish between reliable and less reliable sources of information, expects immediate satisfaction and presence from society (Demir \& Sönmez, 2021). These characteristics influence Generation $Z$ learning strategies and styles, making certain methods more effective than others in entrepreneurship education.

ICT tools used in teaching entrepreneurship have been researched and described by Roach [13], Kerr [14], O'Flaherty \& Phillips15, Van Goch (2018), and they involve the incorporation of free apps and free software as learning support. These applications are used in the implementation of active strategies in the classroom, as Flipped Learning. But other strategies have also been used: Problembased Learning, Game-based Learning, Simulation-based Learning, Learning-by-doing, Puzzle-based Learning, Blended-Learning, as complement to Flipped Classroom [16]. This methodology has a pedagogical effectiveness superior to the traditional system. Multimedia resources and ICT tools provide the necessary mechanisms to implement a good educational innovation [17].

There is a set of modern teaching methods that can be used in teaching entrepreneurship that potentially meets the specific characteristics of Generation Z. The most popular to be analyzed in our primary research are the following: simulation games, board games, hackatons, discussions, group works, role play, peer learning and brainstorming, the crucial role play the use of IT tools (Kahoot, Mentimeter and others) [18]. They directly or indirectly include the suggestions of the authors quoted above for appropriate modern approaches in teaching entrepreneurship [19, 20].

\section{Methodology.}

As part of the study a survey was conducted to find answers to the questions raised about the Generation's $Z$ attitude towards modern teaching methods and tools, and how these methods affect business management knowledge. In total, answers were obtained and compiled from 201 respondents residing in Latvia, mostly students from business management and economics field. The principle of sampling was based on the intention to include respondents who have studied business subjects with a use of modern teaching methods and tools. During the questionnaire, the respondents evaluated the effectiveness of modern teaching methods for understanding and learning the topics related to business management. A Likert scale was used and the respondents were asked to evaluate the methods by giving it a quantitative value from 1 to 5 thus measuring the level of disagreement/agreement with the statements. It should be noted that respondents who have not experienced the specific method were excluded from average evaluation of the method. The survey was conducted in the first half of 2020.

In the course of the research the preferences of the type of study were also clarified. Respondents had to make a choice between learning in a classical way, modern way, blended or remote. Hypothesis test for differences in respondents' answers about the most appropriate methods depending on the preferred type of study afterwards was made.

\section{Results.}

The results of the survey among Latvians have led to a number of important findings. Asked to assess on a Likert scale of 1-5 to what extent the application of modern methods helps to acquire entrepreneurial knowledge, the average rating reached 4.27. A standard deviation of 0.899 was 
calculated for this indicator, which shows that provided answers jumped relatively close to the average value. From this it can be concluded that even the most pessimistic respondents believe that it is more possible than impossible to acquire knowledge in this way.

When asked to rate the effectiveness of different modern teaching methods on a scale of 1 to 5 , where " 1 " indicates "ineffective" and " 5 " indicates an effective teaching method, the highest rated method is peer learning or learning from colleagues/other people. cooperative learning, with an average grade of 4.13 . Simulation games with a rating of 4.05 are in the 2 nd place, while respondents valued board games as the least effective of the methods, however such classical teaching method as discussion is rated at 3.82, higher as using of IT tools. Figure 1 reveals that, although board games are rated at an average of 3.18, it is not considered inefficient. According to the answers provided, a value of 3 indicates a moderately efficient method, so it can still be used as a good enough in specific cases.

Figure 1. Evaluation of the appropriateness of modern teaching methods and tools (range 1-5, with indication of the standard deviation).

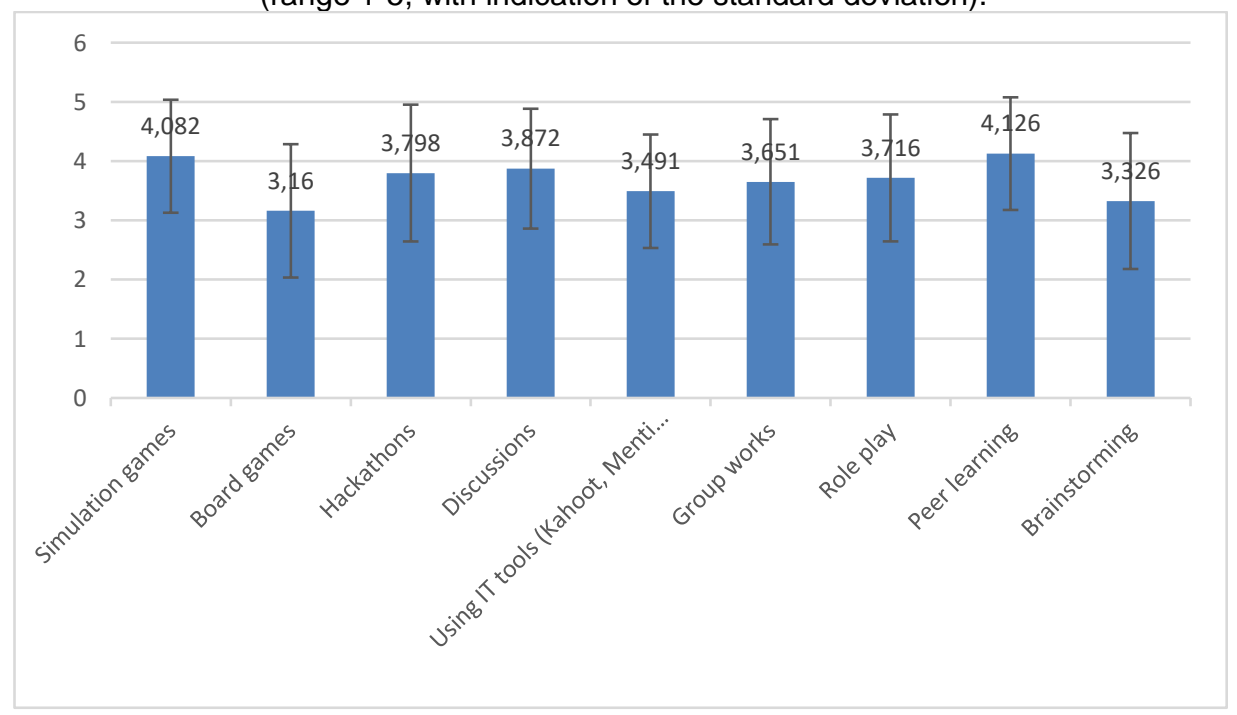

During the analysis the authors were founding out that investments in Fintech companies have grown particularly rapidly in recent years, with 2018 and 2019 average investments in Fintech were 20 times higher than in 2010 and 2011 average but 46 times higher in Europe as shown in Figure 2. Particularly rapid investment growth was observed in 2018, when total investments more than doubled. This was largely due to a single investment in China amounting to US\$ 14 billion [21].

Analysis of the preferred type of learning reveals that $52 \%$ of respondents prefer learning entrepreneurship in a blended way if there was such an opportunity. In turn, $33.8 \%$ indicate that they would like to learn it in a modern way. As both of these types of teaching include the abovementioned teaching methods, it can be concluded that $86.1 \%$ consider application of modern teaching methods in entrepreneurship education as important and preferable. However, the fact that most respondents prefer blended learning indicates that classical teaching methods are also an important and integral part of teaching processes.

Survey reveals also that the evaluation of appropriateness of modern methods is different depending on preferred type of learning. By performing the Chi-square test, three teaching methods can be identified as having an assessment that depends on the type of teaching that the respondents would choose. Looking at Figure 2, it can be seen that discussions, group work and role plays have a $p$ -value of less than 0.05 . Thus, the chosen type of teaching is an important factor in the evaluation of these three methods. 
Figure 2. Evaluation of methods depending on the preferred type of learning (range 1-5, with indication of the standard deviation).

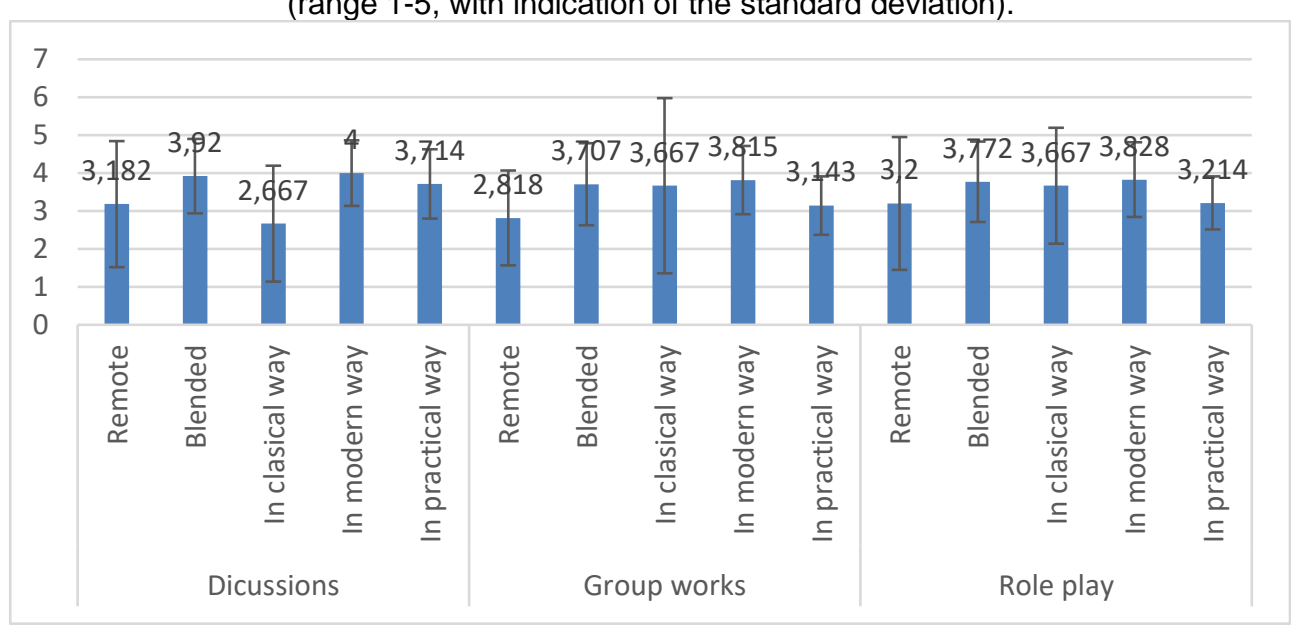

Looking at these results in more detail, it is clear that all three methods are highly valued by respondents who have a preference to learn in a modern way. Proponents of blended learning give the second highest rating for these methods [23-25]. The figure 2 shows that group work and role play are rated the lowest by people who have chosen distance learning, but discussions have lowest score from those who prefer classical studies. The low evaluation of role plays and group works from those who would prefer learning remotely is understandable, because it is very difficult to work in a group or implement a role-playing game while studying online.

The survey allows to conclude that respondents highly value the application and appropriateness of modern teaching methods in business studies, however, the evaluation of different methods differs significantly depending on the type of learning preferred by respondents.

\section{Discussion.}

This study mainly coincides with or complements the results of similar studies.

The use of modern methods in the learning process does not change the content to be delivered to the learner. As Perdue [26] argues, incorporating the practice and development of 21st century skills into the higher education humanities classroom does not necessarily require a great rethinking of the education model or content delivery. Rather, it could be as simple as encouraging faculty to use proven educational principles such as active learning and group-based learning into the classroom. In many ways, the outcomes can contribute to the flipped classroom strategy which is becoming more popular nowadays.

Artal-Sevil et al [17] describe Flipped Teaching or inverted class methodology which consists in that the students prepare certain learning contents outside the classroom, usually as homework. Thus it is possible to perform other much more practical academic tasks in the classroom. The use of interactive tools has allowed that the classroom sessions can be more interactive, increasing the motivation of the students. Thus method facilitates interaction and knowledge construction through a collaborative learning. Bergmann and Sams [19] explain that a Flipped Classroom is a classroom with mixed direct instructions that focus on constructing students based on the subject.

It is also important to develop teaching practices and tools following the opportunities created by digitalization and emergence of artificial intelligence. Mavlutova et al [24] and Van Goch [27] emphasize that in order to stimulate entrepreneurial intentions among students, teachers should use developed practical tools like automatic digital software for assessment of business ideas of young entrepreneurs, checking of financial plans through automatic digital systems, to adapt them and to include such practices in course syllabus, thus offering better education practices. 


\section{Conclusions.}

From the analysis of statistics on the development of the financial sector, changes in its landscape and two hypotheses testing, the authors concluded that there is strong evidence that allocated investments to various Fintech services are statistically different.

Youngsters of Generation Z are cautious, hard-working and want to build a career in a stable environment. They do not know the world without the internet, virtual reality has become as real as the physical world in their lives. In respect to learning entrepreneurship, it means that different teaching methods should be applied for this generation.

Technological progress provides an opportunity to use modern methods and modern ways in the process of entrepreneurship education- internet tools, internet of things and many others. In contrast to the classical way of listening to the lectures, Generation Z prefers simulation and peer learning but at the same time they like discussions more and less working in groups as well as brainstorming.

Our survey of Generation Z in Latvia allows to conclude that respondents surveyed highly value the application and appropriateness of modern teaching methods in business studies, however, the evaluation of different methods differs significantly depending on the type of learning prefered by respondents.

There are certain limitations for generalizing the outcomes gotten from the surveying Latvian youngsters as Latvia for many years stands out in the EU with its relatively high entrepreneurial activity. Thus, further research is needed to investigate the attitudes in other geographical regions and countries.

\section{Acknowledgements}

The paper was supported by the BA School of Business and Finance project "Modern teaching methods to promote the development of sustainable entrepreneurial thinking".

\section{References}

1. Mavlutova, I., Lesinskis, K., Liogys, M., Hermanis, J. (2020). Innovative teaching techniques for entrepreneurship education in the era of digitalisation. WSEAS TRANSACTIONS on ENVIRONMENT and DEVELOPMENT, ISSN: 1790-5079. DOI: 10.37394/232015.2020.16.75

2. Audretsch, D., B. (2014). From the entrepreneurial university to the university for the entrepreneurial society. Journal of Technology Transfer, Vols. 39, No. 3, pp. 313-321.

3. Uvarova, I, Mavlutova, I, Atstaja, D. (2020) Development of the green entrepreneurial mindset through modern entrepreneurship education. The IOP Conference Series: Earth and Environmental Science, I 628 012034, pp.1-13. DOI: 10.1088/issn.1755-1315

4. Petrova, M., Koval, V., Tepavicharova, M., Zerkal, A., Radchenko, A., \& Bondarchuk, N. (2020). The interaction between the human resources motivation and the commitment to the organization. Journal of Security and Sustainability Issues, 9(3), 897-907. DOI: 10.9770/jssi.2020.9.3(15)

5. Neck, H., Greene, P. (2011). Entrepreneurship Education: Known Worlds and New Frontiers. Journal of Small Business Management, 49(1): 55-70. DOI: 10.1111/j.1540-627X.2010.00314.x

6. Fiet, J. O. (2014). The relationship between entrepreneurship education and entrepreneurial intentions: A meta-analytic review. Entrepreneurship Theory \& Practice, 38(2), 217-254.

7. Hattab, H.W. (2014). Impact of entrepreneurship education on entrepreneurial intentions of university students in Egypt. The Journal of Entrepreneurship, 23(1), 1-18.

8. Chillakuri, B., \& Mahanandia, R.(2018). Generation Z enter ing the workforce: the need for sustainable strategies inmaximizing their talent .Human Resource Management Digest, Vol 26, Iss:4, 34 - 38. DOI: 10.1108/HRMID-01-2018-0006

9. Schawbel, D. (2014). Gen Z employees: The 5 attributes you need to know. Entrepreneur Europe, 
https://www.entrepreneur.com/article/236560

10.Ferguson, N. \& Freimann, E. (2019). The coming generation war. The Atlantic. https://www.theatlantic.com/ideas/archive/2019/05/coming-generation-war/588670/

11.Scholz, C, Rennig, A. (2019) Generations Z in Europe: Inputs, Insights and Implications (Changing Context of Managing People), Bingley, UK: Emerald Publishing Limited.

12.Iftode, D. (2019) Generation Z and Learning Styles. SSRN Electronic Journal 21:3, 255-262. DOI: 10.2139/SSRN.3518722.

13.Roach, T. (2014). Student perceptions toward flipped learning: New methods to increase interaction and active learning in economics. International Review of Economics Education. vol. 17, 74 - 84. DOI:10.1016/J.IREE.2014.08.003

14.Kerr, B. (2015). The flipped classroom in engineering education: A survey of the research. International Conference on Interactive Collaborative Learning (ICL 2015). IEE, 815 - 818.

15.O'Flaherty, J. \& Phillips, C. (2015). The use of flipped classrooms in higher education: A scoping review. Internet and Higher Education, 25(1), 85-95. Elsevier Ltd.

16.Luchaninova, O., Koval, V., Deforzh, H., Nakonechna, L. \& Golovnia, O. (2019). Formation of communicative competence of future specialists by means of group work. Espacios, 40 (41), 11.

17.Artal-Sevil, J., Castel A. \& Gracia, M. (2020). Flipped Teaching and interactive tools. A multidisciplinary innovation experience in higher education. 6th International Conference on Higher Education Advances (HEAd'20), 103 -112. DOI: 10.4995/HEAd20.2020.11008

18.Kahoot (2017). Game-based learning platform. https://kahoot.com/what-is-kahoot/.

19.Bergmann J. and Sams A. (2012). Flip your classroom: Reach every student in every class every day. Eugene, Oregon, USA: International Society for Technology in Education.

20.Arsawan, I.W.E., Koval, V., Rajiani, I., Rustiarini, N.W., Supartha, W.G. and Suryantini, N.P.S. (2020). Leveraging knowledge sharing and innovation culture into SMEs sustainable competitive advantage. International Journal of Productivity and Performance Management (in press). DOI: 10.1108/IJPPM-04-2020-0192

21.Accenture (2019). Accenture study finds growing demand for digital health services revolutionizing delivery models: Patients, doctors + machines. https://accntu.re/2H8KsE9

22.Demir, B. \& Sönmez, G. (2021). Generation Z students' expectations from English language instruction. Journal of Language and Linguistic Studies, 17: 1, 683-701

23.Yeshchenko, M., Koval, V., \& Tsvirko, O. (2019). Economic policy priorities of the income regulation. Espacios, 40 (38), 11.

24.Mavlutova, I., Lesinskis, K., Liogys, M., Hermanis, J. (2020). The Role of Innovative Methods in Teaching Entrepreneurship in Higher Education: Multidisciplinary Approach, chapter, In book: Reliability and Statistics in Transportation and Communication, Editors: I. Kabashkin, I. Jatskiv, O. Prentkovskis, pp.684-693. DOI: 10.1007/978-3-030-44610-9_66

25. Hutsaliuk, O., Koval, V., Tsimoshynska, O., Koval, M., Skyba, H. (2020). Risk Management of Forming Enterprises Integration Corporate Strategy. TEM Journal, 9(4), 1514-1523. https://doi.org/10.18421/TEM94-26

26.Perdue, M. (2020). Practicing 21st Century Skills in the Classroom. 6th International Conference on Higher Education Advances (HEAd'20), 85-94. DOI: 10.4995/HEAd20.2020.11008

27.Van Goch, M. (2018). Creativity in liberal education before and after study commencement. 4th International Conference on Higher Education Advances (HEAd'18), 1475-1483. DOI: 10.4995/HEAd18.2018.8228. 